This is an Author's Accepted Manuscript of an article published in Conflict, Security \& Development, Volume 5, Number 2, 2005, pp.247-268 (copyright Routledge/Taylor \& Francis), available online at: http://www.tandfonline.com/doi/pdf/10.1080/14678800500170209\#.UvzfsqOcYkA

\title{
Security Governance and the Private Military Industry in Europe and North America
}

\author{
Elke Krahmann
}

\begin{abstract}
Even before Iraq the growing use of private military contractors has been widely discussed in the academic and public literature. However, the reasons for this proliferation of private military companies and its implications are frequently generalized due to a lack of suitable theoretical approaches for the analysis of private means of violence in contemporary security. As a consequence, this article contends, the analysis of the growth of the private military industry typically conflates two separate developments: the failure of some developing states to provide for their national security and the privatisation of military services in industrialized nations in Europe and North America. This article focuses on the latter and argues that the concept of security governance can be used as a theoretical framework for understanding the distinct development, problems and solutions for the governance of the private military industry in developed countries.
\end{abstract}

\section{Introduction}

As the recent intervention in Iraq has highlighted the increasing role of private military firms in international security, the proliferation of the "new mercenaries" (Adams, 1999) has been widely criticised. However, when offering an assessment of the private military industry, many authors have tended to conflate the rise of the industry in Europe and [end of p.247] North America with that in the Third World (e.g. Singer, 2003; Nossal, 2001). As a consequence these studies frequently generalize the controversial involvement of now-disbanded companies such as Executive Outcomes and Sandline International in regional conflicts such as in Angola and Sierra Leone, while the primary growth of the private security industry has been in Europe and North America where governments have pursued the outsourcing of military services since the mid-1990s (Krahmann, 2005b). By 2002 the United Kingdom thus had outsourced military services in excess of $£ 1.4$ billion and was considering more than ninety new projects with an estimated value of $£ 6$ billion ranging from the training of Royal Air Force pilots and Navy personnel to the provision of spare parts and logistics (MoD, 2004a). Similarly, the United States (U.S.) has progressively expanded its employment of private military contractors for military and military support services since the 1990s (Markusen, 2003: 474-477). Moreover, in addition to the outsourcing of national security, countries in Europe and North America are increasingly using private companies in international interventions such as in the former Yugoslavia, Afghanistan and Iraq (Isenberg, 2004; Spearin 2003). In fact, the number of private military contractors employed in overseas operations has increased from in the region of 1:100 in the first Gulf War to 1:10 in the current operation in Iraq (Spearin, 2003: 28).

Contending that the outsourcing of military services by governments in Europe and North America needs to be distinguished from the use of mercenary firms in the developing world, this article aims to provide a theoretically guided analysis and explanation of the origins, problems and potential means of governance of military outsourcing in the transatlantic regions. It justifies its focus on Europe and North America with three arguments. First, most of the revenue of private military companies stems from services provided to governments and private actors in the transatlantic region. Moreover, industrialized nations appear to be the primary growth area for the private military industry as these firms are increasingly viewed as legitimate actors in European and North American security (Lilly, 2000: 7). 
Second, the outsourcing of security services within the transatlantic community differs in many respects from the use of private military firms in the Third World where it has been associated with weak or 'failed' states (Aning, 2001; Holmqvist, 2005: 11-17). This article proposes that the privatisation of security in Europe and North America, unlike that in developing countries, can be understood as part of the emergence of a new system of 'security governance' in the post-Cold War era. The concept of security governance explains the transformation of transatlantic security policy from [end of p.248] the state-centred bias and bipolar structure of the Cold War towards a complex system of functionally differentiated networks which involve both public and private security providers.

Third, the development, problems and options for the regulation of these firms in Europe and North America are crucial for defining the international role of private military companies. Since most of these companies are based in industrialized countries, they can be, even when contracted by ThirdWorld actors, subject to the legal and normative restraints imposed by Western governments. Moreover, due to the large role of European and North American governments in the provision of security and development aid to Third World countries, Western governments are able to influence how private military companies may be used in local operations. Finally, European and North American governments determine which companies are considered for contracts in international peacekeeping missions or by international organizations in which they are members.

In the following, this article is structured in three parts. The first part examines how the concept of security governance can help to understand the growing use of private military contractors by governments in Europe and North America. The second part discusses its contribution to understanding the specific problems which have been linked to the outsourcing of military functions to private companies in the transatlantic region. And the third part, investigates how to the concept of security governance can help to identify suitable mechanisms for addressing these problems.

\section{Security Governance and the Proliferation of Private Military Companies}

While the use of private military companies in the Third World has been controversial but limited, the employment of private military companies by governments in Europe and North America has grown exponentially since the 1990s. Three main explanatory factors have been proposed in the academic literature for the accelerated growth of these companies over the past two decades. The first factor is the increased demand generated by the outbreak of small conflicts in the Third World where fragile regimes can no longer count on the financial and military support of one of the two superpowers (Brooks, 2000: 132; Singer, 2003: 55). The second factor is a decreased willingness of European and North American governments to engage in international peacekeeping [end of p.249] operations unless their immediate security interests are concerned, following the failure of missions such as in Somalia in the early 1990s (Brooks, 2000: 134; Taulbee, 2000:434f.; Cleaver, 2000: 137; Singer, 2003: 58). The third factor is the reduction of defence budgets and the rising cost of military technology and operations in particular after the end of the Cold War (Arnold, 1999: 173; Singer, 2003: 67; Spearin, 2003: 28).

This article suggests that the above explanations for the growth of the private military industry subsume two analytically distinct developments. The first factor refers to the lack of credible military forces, which is often linked to the notion of failed statehood in the Third World. The latter two factors can be explained by the emergence of a system of 'security governance' in Europe and North America where states continue to uphold substantial and sophisticated military forces, but choose to subcontract part of their national or international security functions to private companies.

This trend from 'government' to 'security governance' in European and North America is characterized by the fragmentation of security policy making in seven key dimensions: geography, function, distribution of resources, interests, norms, decision-making and policy implementation (Krahmann, 2003a). Each dimension can take a variety of forms along a scale between the ideal notions of 'government' and 'security governance' as defined in Table $1 .{ }^{1}$ 
Obviously, it is difficult to specify which or how many dimensions have to be fragmented for a policy making structure to qualify as 'governance' rather than 'government'. ${ }^{2}$ Most contemporary security policy making arrangements would be placed somewhere between these two ideal types.

Moreover, security arrangements in North America and Europe are constantly evolving, although not all dimensions shift at the same speed. Thus it appears that changes in some dimensions are promoting those in others in order to achieve internally consistent systems which are suggested by the ideal types of 'government' and 'security governance'. Combined with the transformation of the international security environment, these changes can serve as explanatory variables for the progressive shift from 'government' to 'security governance' (Krahmann, 2005a: 27-28). Specifically, it can be argued that the replacement of interstate war as the most important source of insecurity in Europe and North America by military, political, social, economic and environmental threats, such as terrorism, proliferation and civil conflicts, is challenging the ability of sovereign nation-states to ensure the security of their citizens. As a consequence, states within the transatlantic region progressively recognize the resources and expertise of non-state actors such as [end of p.250] international organizations which can help to improve their national and international security. This shift is supported by a change in the norms underlying public policy making which consider efficiency and cost-effectiveness in security policy making as more important than state sovereignty and the maintenance of the state monopoly on the legitimate use of force. In short, changes in three dimensions appear to be promoting the transformation from 'government' to 'security governance': functional fragmentation due to the rise of non-state security threats, resource fragmentation due to the diversity of skills and capabilities required in dealing with these threats, and normative changes from ideology and state sovereignty to cost-efficiency.

Table 1. 'Government' and 'Security Governance' as Ideal Types

\section{Government}

DIMENSIONS

state

regional

Geographical scope

Military

Functional scope

centralised in states and NATO/ WTO

Distribution of
resources

Interests

Norms

Decision-making

Implementation
Common

sovereignty

'one for all, all for one'

ideological priorities

centralised

consensus

formal equality

centralised

authoritative
Security Governance 
For the emergence of 'security governance', several hypotheses follow which suggest that changes in the other dimensions can be linked to these transformations. First, the diversification of security threats and the differentiation of resources [end of p.251] and capabilities among state and non-state actors suggests the growing geographical fragmentation of security policy making among multiple and diverse sets of actors at the subnational, national, regional and global levels. Second, because of the non-state nature of the new security challenges we are likely to observe the differentiation of security interests and, due to the decreased threat from interstate war cooperation, can proceed within more flexible coalitions of the willing which are more suited to accommodate the complex and regionally differentiated impact and interests related to non-state security threats. Third, the complexity of the new threats, the weakening of the state monopoly on the provision of security and the rise of cost-efficiency as legitimising mechanism promote changes in the making and implementation of security policy making. In particular, they will encourage functional specialization and differentiation among state and non-state actors, and lead to fragmented and voluntary decisionmaking and implementation arrangements which typically rely on negotiated forms of cooperation among multiple actors, such as contracts.

In security, these changes appear to have well progressed towards 'security governance' through the broadening of the notion of security from military to non-military threats and in terms of resource fragmentation. However, in the other dimensions there appears to be a slower development. The problems which arise from this for the internal logic and functioning of these security arrangements and their consequences will be discussed in more detail in the second part of this article. Nevertheless, it can be argued that in the area of national and international security a transformation from 'government' to 'security governance' can be detected since the end of the Cold War (Krahmann, 2003a). The following examines how the proliferation of private military companies in Europe and North America can be explained by this transformation.

The perceived increase in 'new' security threats, such as ethnic war, international terrorism and transnational crime, has been one of the key factors promoting the growing role of private security providers as it created new demand for security services. Importantly, in Europe and North America this demand could only in part be met by existing national armed forces that had just been cut back after the end of the Cold War due to public calls for a peace dividend (Spearin, 2003: 28; Carver, 1992: 155; Croft and Dunn, 1990). Following the widespread reduction of armed forces and military support units in Europe and North America, these states were unprepared for the new threats and more interventionist approaches to national and international security which were adopted after the break-up of Yugoslavia and 11 September 2001. As a consequence, governments have been induced to turn to private military companies, which could be called upon on short notice, to supplement their forces. [end of p.252]

The second crucial factor contributing to the emergence of a private military industry in Europe and North America has been the fragmentation of military resources and capabilities between public and private actors. In addition to Cold War-related reductions in defence spending, defence budgets have become strained due to the rising costs of standing armies, professional training, and armaments research and development (Greenwood, 1991; Smith, 1993; Spearin, 2003; 29-30). Many Western governments increasingly rely on public-private partnerships with private defence corporations in order to fund new defence investments and military technologies (Gates and Robbert, 1998; Pint and Hart, 2001; Krahmann, 2005b).

This shift from the centralization of resources through taxation and government spending in national and international security to a fragmented mode is represented by shift to Private Finance Initiatives (PFIs) as 'first choice method of funding new capital projects' by the British Ministry of Defence (MoD, 2004a) ${ }^{3}$. In these schemes private companies to bid for not only for the servicing, but also the construction and maintenance of military facilities. The investment into the building of such facilities is financed by the private sector in return for military service contracts which typically last between ten and forty years and guarantee continuous income in the form of agreed fees. In addition, some PFIs allow companies to generate 'third party revenue' from the sale of spare capacities to private customers. Although the cumulative cost for the provision of these facilities will tend to be 
higher than if they had been financed by the government, Western industrialised countries increasingly prefer PFIs because they spread the cost of a military project more evenly over the duration of the contract. This eliminates the difficulties of having to secure parliamentary approval for projects with huge start-up costs in a particular budget year. However, since the facilities are funded by the private sector, they remain in private hands and thus further contribute to the fragmentation of military resources among public and private actors.

The third critical transformation has been in the weakening of ideology and national sovereignty as central norms in national and international security policy making in favour of economy and cost-efficiency (Spearin, 2003: 29). In contemporary Europe and North America, the high defence spending which contributed to the dissolution of the Soviet Union and placed significant burdens on Western industrialized nations is no longer acceptable. Instead governments and the electorate are calling for 'value for money' in defence spending (Howe, 1998; Brooks, 2000: 131; Markusen, 2003: 477-8). [end of p.253]

Moreover, in an attempt to further increase efficiency, governments are allowing private companies to take over functions which until recently were regarded as the monopoly of the state. In Europe this has led not only to the progressive privatisation of national defence industries, but also to the acceptance of transnational mergers in the armaments and military service sectors. While during the Cold War, an independent national deterrent was closely linked to the raison d'être of states like the United Kingdom and France, the 1990s have seen the transnational integration of the defence sector across Europe and North America (Bitzinger, 1994; Skoens and Wulf, 1994). Today large transnational defence corporations and private military companies are increasingly dominating the international market with firms such as Lockheed Martin, BAE Systems, EADS and Thales providing not only the goods but, through subsidiaries, frequently also the associated military services such as training and maintenance.

One of the results of these changes is the progressive geographical fragmentation of security policy making. In the post-Cold War era, this development has resulted in two trends: an 'upward' shift towards regional and global institutions of governance and a 'sideways' shift towards private security providers. The upward trend has been identified with the geographical expansion of NATO and the EU as well as a growing number of regional and sub-regional institutions (Cottey, 2000). The 'sideways' trend has ranged from the privatisation of the armaments industry (Lovering, 1998; James, 2000) to the outsourcing of military services such as logistics, transport and training to private military companies in Europe and North America (Matthews and Parker, 1999; Mandel, 2002; Krahmann, 2005b).

Crucially the use of private military companies within a geographically fragmented security architecture not only offers the prospect of decreased spending on military services, but also enables European and North American governments to intervene globally with greater flexibility. In particular, the use or tacit approval of private military companies operating in international conflicts or post-conflict reconstruction allows Western democratic governments to circumvent public opposition against foreign interventions. Most recently, the governments of the United Kingdom and the United States have been accused of having withheld prior intelligence about the intended mercenary coup in Equatorial Guinea which was funded by British and South African backers including Sir Mark Thatcher, the son of former UK Prime Minister Margaret Thatcher (Observer, 24/11/04; Guardian 27/9/04). In addition, the United States has licensed a contract between the Virginia-based private military company Military Professional Resources Inc. (MPRI) and the Croat [end of p.254] government for the training of the newly formed Croat armed forces which is alleged to have contributed to the expulsion ethnic Serbs from the Krajina region. Finally, the British Foreign Office has been accused of having implicitly approved the involvement of London-based Sandline International in Sierra Leone (Sunday Times 3/5/98; Times 4/5/98; Cleaver, 2000: 142-43).

A further consequence is the differentiation of security functions among state and non-state security providers. In particular, the growing emphasis on non-traditional areas of security combined with the limited expertise, the reduction in military personnel and the resources of governments in these areas has strengthened the role of private actors in security governance. The provision of humanitarian aid in complex emergencies such as the former Yugoslavia, for instance, relied on a 
multitude of national and international non-governmental organizations for the provision of basic security needs such as shelter, food, water and health care. In addition, defence ministries in Europe and North America seek to exploit the expertise of private companies through the outsourcing of support functions, including base maintenance, estate management and logistics. In the military sector, thus, a division of labour appears to emerge between combat, which so far remains the exclusive domain of national armed forces in Western democracies, and non-combat functions, which are progressively delegated to the private sector.

In addition to changes in structure of security provision, the shift from 'government' to 'security governance' is fostering a transformation in how security interests are perceived in the Cold War era, which helps to explain the increasing role of private military companies in the transatlantic community. Specifically, there has been a growing willingness to recognize the diverse security interests of states in Europe and North America with regard to different types of threats ranging from ethnic conflicts to terrorism and transnational crime. The creation of an independent European Common Security and Defence Policy stands for the European aim to provide for its own security and create the necessary capabilities. NATO, too, has progressed toward a more flexible structure with the development of the Combined Joint Task Forces which allows the formation of "coalitions of the willing".

This trend towards a differentiation of interests directly contributes to the growing demand for private military companies because they allow American and European governments to act more independently in their provision of national and international security (Spearin, 2003: 35). While during the Cold War Europe frequently depended upon the United States and the Atlantic Alliance for military support such as transport or logistics [end of p.255], private military companies are now offering these services on the international market. Until the expected completion of the Future Large Transport Aircraft in 2009, the United Kingdom is thus relying on private airlift capacity such as Antonov planes which have been used during the international intervention in Kosovo (NAO, 2000: 34; Airbus, 2005). Other contracts for the private provision of military transport capabilities include the six Roll-on Roll-off Ferries of the British Armed Forces which are chartered on a permanent or ad hoc basis under a PFI scheme running until 2024 (MoD, 2003).

Finally, these changes are facilitating the transformation of security policy decision-making and implementation in Europe and North America. While traditionally government and, especially, the military have heavily relied on hierarchical structures, the introduction of new public management principles in order to increase cost-efficiency and the growing reliance on the capabilities of private security companies have encouraged the establishment of more horizontal relationships in the defence sector. Through public private partnerships and private finance, these arrangements move away from decision-making and implementation structures in which the government directed private service suppliers to cooperative relations in which private firms are involved as partners in defining policies and their implementation (MoD, 2004b).

Moreover, due to the above developments, the implementation of security policies in Europe and North America is becoming more and more fragmented and allows for a greater role of private military companies. Although most security policy decisions are still taken in the final instance by national governments and international organizations, private companies not only implement these policies at the national level, but also, increasingly, abroad. Moreover, the partnership arrangements between public and private actors give private military companies more freedom in the way they implement security policies. In fact, the idea of public private partnerships is based on the assumption that private companies will be able to operate the more cost-efficiently the less they are impeded by governmental or contractual direction. This collaborative spirit, however, presumes that private military companies will voluntarily operate in the best interest of the government and will not exploit their freedom to increase profits.

The preceding analysis has suggested that the proliferation of private military companies in Europe and North America can be explained by the shift from 'government' to 'security governance'. As has been suggested, the degree of this shift can vary considerably across different dimensions. Whereas it seems to have progressed most in the geographical and functional fragmentation of security policy making, other [end of p.256] dimensions such as decision-making and implementation 
are still in the process of adapting to new modes of governance. The following section examines how these differences can lead to governance failure.

\section{Private Military Companies and Governance Failure}

While the growing use of private military companies helps to lower the pressures on the resources of governments and international organisations, it has also been linked to a range of governance failures (Isenberg, 2004: 39-49; Taulbee 2000: 436; Zarate 1998: 77). This section suggests that the shift from government to security governance can help to understand why. It proposes that governance failures arise when the transformation from a system of centralized 'government' to a fragmented system of 'security governance' in some of the identified seven dimensions is not matched by congruent changes in the other dimensions. The results are internal inconsistencies which can lead to normative and practical tensions. Normative failures specifically arise when changes in the policy process are not consistent with prevailing norms and beliefs. Whereas practical governance failures emerge from mismatches across the non-ideational dimensions of 'government' and 'governance' as ideal types, such as geographical and functional scope, resource distribution, and policy making and implementation. The following discusses three sets of governance failures in detail: lack of transparency and accountability, loss of control, and decreased efficiency.

\section{Transparency and accountability}

Lack of transparency and public accountability are among the most frequently noted problems in the governance of private military companies (Singer, 2003: 152-4; Holmqvist, 2005: 28-9; Grant 1998; Howe 1998; Silverstein 1997; Lovering 1998: 233; Edmonds: 1999:126). Both are essentially normative concerns and can be explained by the observation that the fragmentation of functions and resources among public and private security providers clashes with persistent norms concerning responsible 'government' and democratic decision-making processes which have been developed in Europe and North America during the Cold-War era.

One way in which the emergence of security governance is challenging established norms and decision-making arrangements is the dissolution of clear lines of responsibility. [end of p.257] While under 'government' political responsibility rests with the legislative and executive, in 'governance' it is distributed among a multiplicity of public and private actors (Krahmann, 2003b). Since these actors cooperate in the making and implementation of security policies, no single actor can be held accountable for the outcomes of this process. In Iraq, for instance, public accountability and oversight has been made more difficult not only by the employment of a large number of private military firms for services ranging from the provision of military logistics and training to the interrogation of detainees in the infamous Abu Ghraib prison, but also because these firms frequently use national and local subcontractors (Isenberg, 2004: 69-71; Spearin, 2003: 39-40).

Moreover, governments and private military companies are accountable to different actors. While governments are answerable to the electorate, private military companies are responsible to their shareholders and customers (Edmonds 1999: 126; Markusen, 2003: 488). Only the former is accountable to the general public and hence under the scrutiny of parliamentary inquiries and the media. Although private armaments and security companies make some data available to shareholders, detailed information on where armaments and services are sold and for what purpose are not published for a broader audience (Markusen 2003: 6). Even when governments employ private military companies, the details of these contracts are rarely made public. Moreover, while there has been increasing demand for the publication of data on national arms exports, the military service industry has so far avoided calls for greater transparency.

It can thus be argued that the perceived loss of transparency and accountability due to the outsourcing of security functions to private military companies is a consequence of norms that have 
been developed and, so far, enforced within the context of centralized structures of 'government' which are unsuited to the emerging system of 'governance'.

\section{Governmental Control}

The loss of governmental control over security policy is the second normative problem which can be explained by the shift from 'government' to 'security governance' (Grant 1998: 2; Howe 1998; Zarate 1998: 146). Specifically, the progressive privatisation and internationalisation of the security industry and the consequent fragmentation of security policy making in terms of geography, function and distribution of resources contributes to the reduction of immediate governmental control over national and international security. However, while the fragmentation political authority among multiple actors is not [end of p.258] synonymous with governance failure in policy sectors such as education or the environment, it is perceived as a problem in security because the loss of governmental control contradicts persistent popular beliefs in European and North American according to which the state should have the monopoly on the legitimate use of violence and be sovereign in its provision of national security. Additional problems arise from the fact that the interests of profit-oriented private security companies are not necessarily congruent with those of a government or the general public (Markusen, 2003: 473).

The loss of governmental control over security governance primarily appears to be due to two developments. The first development is the ability of private security firms to evade national controls. The second is the changing balance of power between the state and private security companies. The internationalisation of the private military industry has contributed to both. In particular, it has enabled private military companies to exploit weak controls over the private military service industry. The absence of strict and comprehensive national and international regulation is due to the relatively recent and exponential growth of private military companies which began in the 1990s. Governments and international organisations in Europe have only been catching up with this development in the last few years (Krahmann, 2005b; Krahmann, 2005c), while the United States has required licences for the export of private military services for some time (Nossal 2001: 465; Taulbee 2000: 440; Zarate 1998: 138).

In addition, the ability of Western governments to control the private military sector has been reduced by changes in the relative power of public and private actors (Singer, 2003: 187). With the outsourcing of military functions to private military companies, governments in Europe and North America are becoming more dependent upon private actors for the provision of security. The expertise and information advantage of private military companies and the simultaneous erosion of relevant expertise among public agencies as the consequence of persistent outsourcing allow private firms to influence governmental security policies (Markusen, 2003: 484; Spearin, 2003: 37). Today, private military corporations are as much involved in the definition of security threats and policies as in their implementation (Spearin, 2003: 35). Moreover, flexible modern contracts based on 'indefinitedelivery and indefinite-quantity' and 'cost-plus award fee' principles grant private security actors more freedom in how they implement security tasks identified by the government (GAO 2000).

Finally, the consolidation of the military equipment and service sectors into a decreasing number of large corporations, such MPRI-L-3 Communications (acquired 2000), Vinnell-[end of p.259]Northrop Gumman (2002), DynCorp-CSC (2003) and Group 4-Securior (2004), is reducing the ability of governments to choose between competing private security providers (SIPRI, 2005; Markusen, 2003; 478). Thus, even where governments are dissatisfied with the provision of services, they may have little choice but to continue contracts as not to endanger ongoing operations (Spearin, 2003: 37). A recent example for this dilemma has thus resulted in the decision of the US government not to suspend payments to Kellogg, Brown and Root for overcharging for food provided to troops in Iraq because KBR suggested that this might cause the 'interruption of crucial support services to the U.S. military' (NYT, 3/2/05).

\section{Lack of Efficiency}


Another governance failure which has been noted in Europe and North America is lack of cost efficiency in the making and implementation of security policies. In particular, Kellogg, Brown and Root has repeatedly been accused of overcharging the US armed forces for services provided under its LOGCAP contract in Iraq. Thus, the US Defense Contract Audit Agency found evidence that the company overbilled the government by $\$ 108$ million for fuel imports (NYT, 15/3/05). In addition, auditors have accused KBR of excess charging the armed forces $\$ 160$ million for meals in base camps all over Iraq (GAO, 2004: 26-7; NYT 25/11/04a). Altogether it is estimated that KBR has overcharged the US government by estimated $\$ 2$ billion for contract work in Iraq valued at $\$ 10$ billion (NYT, 25/11/04b).

Already in the former Yugoslavia, KBR had been criticised by the US Government Accounting Office (GAO) for exploiting the flexibility of its indefinite-delivery, indefinite-quantity contract for support services to US operations in the region in order to increase its profits (GAO, 2000). Examples included the installing of a 100 per cent electricity backup for US military bases in Kosovo, although only a few key functions such as the military hospital needed such backups. Other cases of over-provision included the bases' fire fighting services and the cleaning of military quarters for which KBR set much higher standards than those used by the military itself.

That cost-efficiency can be a problem in security governance is especially interesting because the main argument for the shift from public to private service providers is the belief that private companies can offer services at better value for money than governmental agencies. However, if viewed within the context of the shift from [end of p.260] 'government' to 'security governance', it is little surprising. In particular, these inefficiencies can be attributed to the mismatch between changes in security policy making in terms of geography, function, resource distribution and interests on the one hand, and traditional governmental decision-making and implementation arrangements on the other. In particular, it can be argued that these decision-making and implementation structures will have to be adjusted to governance mechanisms because the structure, interests and actions of private military companies are not necessarily congruent with the policy imperatives of the governments that employ them or the states in which they are based. Such governance mechanisms include the development of oversight and control measures appropriate for dealing with fragmented and marketized service provision (Markusen, 2003: 493; GAO, 2004).

While the shift from 'government' to 'governance' appears to be the cause of some problems in the provision of national and international security since the end of the Cold War, it can be argued that new modes of governance can also help to address these problems. The next section discusses the utility of three types of governance mechanisms in particular: self-regulation, contracts, and national and international legislation.

\section{New Modes of Governance}

Due to their focus on mercenaries and private military companies in weak or failing states in the Third World, many analyses have been very sceptic about the possibility of addressing the problems associated with the growth of the private military sector. This section suggests that governance failures within the private military sectors in Europe and North America cannot only be explained by the shift from 'government' to 'governance', but that these ideal types can also help to indicate how the private security sector in industrialised countries might be governed. Specifically, these means need to resolve the tensions inherent in the shift from 'government' to 'governance'. Theoretically there appear to be three options to achieve this. The first option would be to return those dimensions which have progressed most towards 'governance' to more centralized forms of security policy making. The second option would be to develop new mechanisms to overcome the differences between the dimensions without changing their modes of policy making. The third option would be to endorse 'governance' principles in all dimensions. This section will focus on three mechanisms in particular: self-regulation, contractual obligation and regulation. [end of p.261] 
Each of these mechanisms appears to embody to different degrees the three theoretical options for dealing with governance failures which have been outlined above. Self-regulation and contracts can be understood as strengthening fragmented 'governance' as the overriding principle of policy making. Whereas increased governmental and intergovernmental regulation of private military services can be viewed as an attempt to return control to centralized 'government'. Examining each mechanism in turn, this section discusses the effectiveness of these policies.

\section{Self-regulation}

Self-regulation typically refers to a number of mechanisms which can either be used unilaterally or in combinations. They include the licensing of individuals and companies, the setting of training requirements, the establishment of minimum standards of security and insurance, as well as managerial, ethical and operative guidelines. By establishing these standards, self-regulation cannot only increase the transparency and accountability of contractors, but also their cost-efficiency.

In the private military sector, first attempts at self-regulation have been made by the International Peace Operations Association which has designed a voluntary 'Code of Conduct' to which major companies such as ArmorGroup, MPRI and Blackwater have signed up (IPOA, 2005). Other companies have drawn up their own ethics codes, such as Control Risk Group (CRG, 2005), or established company-wide training standards and courses. Additional standards can be found among national security sector organizations such as the British Security Industry Association which requires for ISO 9001 certification and has established standards of proper conduct to which member companies must subscribe (BSIA, 2005).

In spite of these efforts, self-regulation of the private military and security industry has so far been limited. On the one hand, few companies have signed up to voluntary national or international standards, on the other hand, many standards lack convincing monitoring or enforcement structures. Moreover, while a license by an industry association can improve the public credibility of a private military or security company, it is not legally required. Customers may prefer cheaper, non-licensed firms. Finally, transnational companies can evade the controls established by national associations through registering or working abroad. [end of p.262]

In addition to the lack of and problems affecting the self-regulation of the private military industry in practice, the theoretical framework proposed in this article suggests that the ability of self-regulation to address normative governance failures, such as lack of transparency, accountability and control, is already in theory limited. Even if self-regulation were effective, it will be considered insufficient as long as popular norms demand that elected governments are accountable and in control of the provision of national and international security rather than private companies. It follows that for self-regulation to be able to address the perceived lack of transparency, accountability, control and efficiency in the private military sector, there will have to be a normative change from 'government' to 'governance' in security.

\section{Contracts}

In addition to self-regulation, contracts have been proposed as another mechanism for improving the transparency, accountability, control and cost-efficiency of the security industry. Contracts can place similar requirements on private military companies as self-regulation. In particular, governments can ensure that contracts oblige private military companies to publish data on contracts and operations, establish direct channels of control, collaboration and communication between private contractors and the responsible government agencies, and increase the efficiency of private firms by clearly defining tasks and including penalties for non-compliance (Isenberg, 2004: 40). Moreover, contracts between governments and private military firms can overcome the problem of private firms evading national controls because companies are under direct contractual obligation to the government for which they are operating - whether nationally or abroad.

According to the theoretical framework used in the article, contracts are particularly suited for overcoming governance failures created by the shift from 'government' to 'governance' because they involve neither a return to the former, nor demand the full-scale adoption of norms associated with the latter, as does self-regulation. However, there are inherent limitations to the contractual approach to 
governance. In particular, it can be argued that contracts can only address normative concerns such as lack of transparency, accountability and public control, when governments are outsourcing military functions to private providers. Public accountability and transparency are not improved in contracts between private military firms and private businesses, which form a growing pool of [end of p.263] customers. In addition, practical experience from the former Yugoslavia and Iraq illustrates that government agencies are frequently incapable of monitoring and punishing failure to comply with the increasingly complex contracts for the provision of military support services in open-ended international interventions (GAO, 2000; GAO, 2004). Some authors even suggest that the ability of defence ministries to audit public-private contracts will further decline as continued military outsourcing reduces government expertise in these areas and creates long-term dependencies (Markusen, 2003: 479f.). In sum, contracts can only be an effective means of resolving normative and practical governance failures in government outsourcing and only if governments improve their capabilities of managing and monitoring long-term commercial relations with private military companies.

\section{Regulation}

National and international governmental regulation can apply the same standards as self-regulation or contracts. Unlike the latter, however, it can help to ensure public transparency, accountability, control and efficiency not only when governments outsource military services, but also when private military companies are employed by other private actors at home or abroad. Moreover, because national and international regulation represents a return to centralized 'government' as a governing principle, it can help to resolve both the normative and practical governance failures examined above.

As a result, national and international regulation of the private military sector has become increasingly popular in Europe and North America. Among the member states of the European Union, national regulations concerning private security services include personal security and background checks, increasing levels of mandatory training and requirements for the appropriate use and keeping of weapons (CoESS, 2004; Krahmann, 2005b). These regulations also apply to private military companies if they provide support services such as security for military installations within these countries. However, legislation specifically directed at controlling private military companies is being considered by countries such as the United Kingdom and Germany in order to control the export of private security and military services abroad (Independent, 28/11/04; CDU, 2004).

In addition to national controls, there has been the development of similar regulations with regard to private military contractors operating in international interventions. In Iraq they include the vetting and training of personnel as well as the registration and safe storing of company weapons which are only to be carried with government-issued licences [end of p.264] (Isenberg, 2004: 41). These regulations are to be implemented either by the Iraqi Ministries of Trade and Interior for companies working in Iraq (CPA, 2004) or by the US Chief of Mission in the case of private contractors employed by the US government or the multinational forces in Iraq (USG, 2004) - the latter thereby setting new standards for the employment of private military contractors in international operations.

\section{CONCLUSION}

This article has sought to demonstrate that the rise of the private security industry in Europe and North America is analytically distinct from the employment of military firms in the Third World. It suggests that the shift from 'government' to 'security governance' can help to understand this difference in three ways. First, it puts the proliferation of private security firms in Europe and North America into a theoretical context. This context is very different from that of 'failed' statehood which has contributed to the use of private military companies in developing countries. In the transatlantic region, the growth of the private security industry is part of a general transformation towards 
'governance' in which policy sectors that had been centralized before and during the Cold War are being (re)privatised. It suggests that the new role of private military companies in Europe and North America is to a larger degree comparable with similar developments in policy sectors, such as policing, transport and health, than with the emergence of mercenary firms in developing countries which have never acquired these centralized capabilities.

Second, the proposed theoretical framework explains why this development has led to a perceived loss of transparency, accountability, control and efficiency. It argues that these governance failures can be attributed to the internal tensions which emerge from the transformation from a centralized system of 'government' to a fragmented system of 'governance'. Although these problems are widely discussed in the literature, this article helps to understand why they are considered failures in the first place. Moreover, by putting them within the context of 'governance', this article highlights the commonalities of the problems encountered in the privatisation of military services with other privatised policy sectors.

Finally, this article explains why some attempts of resolving these governance failures, notably self-regulation and contracts, may be considered insufficient even if their effectiveness is improved. It proposes that as long as popular norms in Europe and [end of p.265] North America require that security is accountable and controllable through the state and democratic government, private and market mechanisms for enhancing transparency and oversight will not meet expected standards.

\section{Acknowledgements}

The author should like to acknowledge funding from the United States Institute of Peace and the German Academic Exchange Service for this research.

\section{BIBLIOGRAPHY}

Adams, Thomas K. (1999) 'The New Mercenaries and the Privatization of Conflict', Parameters, Summer, pp.103-116.

Airbus (2005) The A400M Programme, at: http://www.airbusmilitary.com/commitment.html\#, last accessed 17 March 2005.

Aning, Emmanuel Kwesi (2001) 'Whither Africa's Security in the New Millennium: State- or Mercenary-induced Stability?' Global Society 15(2): 149-171.

Arnold, Guy (1999) Mercenaries. The Scourge of the Third World. Basingstoke: Macmillan.

Bitzinger, Richard A. (1994) 'The Globalization of the Arms Industry. The Next Proliferation Challenge', International Security 19(2): 170-198.

British Security Industry Association [BSIA] (2005) 'Joining the BSIA', at: http://www.bsia.co.uk/join.html, last accessed 17 March 2005.

Brooks, Doug (2000) 'Messiahs or Mercenaries? The Future of International Military Services', International Peacekeeping 7(4): 129-144.

Carver, Michael (1992) Tightrope Walking: British Defence Policy since 1945. London: Random Century.

CDU (2004) 'Antrag - Nichtstaatliche militärische Sicherheitsunternehmen kontrollieren', Deutscher Bundestag - Drucksache 15/3808, 28 September, at: http://www.ruprechtpolenz.de/presse04/Antrag-Sicherheitsfirmen.pdf, last accessed 6 June 2004.

Cleaver, Gerry (2000) 'Subcontracting Military Power: The Privatization of Security in Contemporary Sub-Saharan Africa', Crime, Law \& Social Change 33(1-2): 131-149.

CoESS [European Confederation of Security Services] (2004) Panoramic Overview of Private Security Industry in the 25 Member States of the European Union, at: http://www.coess.org/studies.htm, last accessed 17 March 2005. 
Control Risks Group (CRG) (2005) 'Ethics Code', at: http://www.crg.com/html/service_level2.php?id=149, last accessed 17 March 2005.

Cottey, Andrew (2000) 'Europe's New Subregionalism', The Journal of Strategic Studies 23(2): 2347.

Coalition Provisional Authority [CPA] (2004) 'Status of the Coalition Provisional Authority, MNF Iraq, Certain Missions and Personnel in Iraq', Order Number 17 (Revised), 27 June, at:

http://www.iraqcoalition.org/regulations/20040627_CPAORD_17_Status_of_Coalition_Rev_with_ Annex_A.pdf, last accessed 17 March 2005.

Croft, Stuart and Dunn, David H. (1990) 'The Impact of the Defence Budget on Arms Control Policy', in Mark Hoffmann (ed.) UK Arms Control Policy in the 1990s, pp.53-69. Manchester: Manchester University Press.

Edmonds, Martin (1999) 'Defense Privatisation: From State Enterprise to Commercialism', Cambridge Review of International Affairs 13 (1):114-129.

GAO [United States Government Accounting Office] (2000) Contingency Operations. Army Should Do More to Control Contract Cost in the Balkans. Washington: GAO.

GAO [renamed: United States Government Accountability Office] (2004) Military Operations. DOD's Extensive Use of Logistics Support Contracts Requires Strengthened Oversight. Washington: GAO.

Gates, Susan M and Robbert, Albert A. (1998) Comparing the Cost of DoD Military and Civil Service Personnel (RAND, MR-980-OSD), at: http://www.rand.org/publications/MR/MR980/MR980.pdf.

Grant, Bruce D. (1998) U.S. Military Expertise for Sale: Private Military Consultants as a Tool of Foreign Policy. Strategy Essay Competition Essay. Institute for National Strategic Studies. at: http://www.ndu.edu/inss/books/essaysch4.html.

Greenwood, David (1991) 'Expenditure and Management', in Peter Byrd (ed.) British Defence Policy: Thatcher and Beyond, pp.36-66. New York: Philip Allan.

Guardian (27/9/04) 'Pentagon Link to Guinea Coup Plot', at: http://www.guardian.co.uk/international/story/0,,1313344,00.html.

Holmqvist, Caroline (2005) Private Security Companies. The Case for Regulation. SIPRI Policy Paper No.9. Stockholm: SIPRI.

Howe, Herbert (1998) 'Global Order and Security Privatization', Strategic Forum, No.140, May, at: http://www.ndu/edu/inss/strforum/forum140.html.

Independent (28/11/04) 'No More Must They Cry Havoc and Let Slip the Dogs of War'.

International Peace Operations Association [IPOA] (2005) Code of Conduct, 31 March, at: http://www.ipoaonline.org/code.htm, last accessed 17 March 2005.

Isenberg, David (2004) A Fistful of Contractors. The Case for a Pragmatic Assessment of Private Military Companies in Iraq. Research Report 2004.4. London: British America Security Information Council.

James, Andrew D. (2000) The Place of the UK Defense Industry in its National Innovation System: Co-evolution of National, Sectoral and Technological Systems, Peace Studies Program Occasional Paper 25. Ithaca: Cornell University.

Krahmann, Elke (2003a) 'Conceptualising Security Governance', Cooperation and Conflict 38(1): 526.

Krahmann, Elke (2003b) 'National, Regional and Global Governance: One Phenomenon or Many?', Global Governance 9(3): 323-346.

Krahmann, Elke (2005a) 'Security Governance and Networks: New Theoretical Perspectives in Transatlantic Security', Cambridge Review of International Affairs 18(1): 19-34.

Krahmann, Elke (2005b) 'Private Military Services in the United Kingdom and Germany: Between Partnership and Regulation', European Security, 
Krahmann, Elke (2005c) 'Regulating Private Military Companies: What Role for the EU?', Contemporary Security Policy, 26(1).

Lilly, Damian (2000) The Privatization of Security and Peacebuilding: A Framework for Action, London: International Alert.

Lovering, John (1998) 'Rebuilding the European Defence Industry in a Competitive World: Intergovernmentalism and the Leading Role Played by Companies', in Mary Kaldor, Ulrich Albrecht and Geniève Schméder (eds.) Restructuring the Global Military Sector. The End of Military Fordism, pp.216-238. London: Pinter.

Mandel, Robert (2002) Armies without States: The Privatization of Security. Boulder, Col: Lynne Rienner.

Markusen, Ann R. (2003) 'The Case Against Privatizing National Security’, Governance, 16(4): 471 501.

Matthew, Ron, and Judith Parker (1999) 'Prime Contracting in Major Defense Contracts', Defense Analysis 15(1): 27-42.

MoD (2003) 'MoD takes delivery of full Ro-Ro ship service twenty months early', at: http://www.mod.uk/dpa/news/pn2003/jun03/roro.htm, last accessed 17 March 2005.

MoD (2004a) 'What Do You Know About...? The Private Finance Initiative', at: http://www.mod.uk/aboutus/keyfacts/factfiles/pfi.htm, last accessed 6 June 2004.

MoD (2004b) 'PFI Guidelines: Case Studies', at: http://www.mod.uk/business/pfi/guidelines/ case_studies.htm, last accessed 6 June 2004.

NAO (2000) Report by the Comptroller and Auditor General, Ministry of Defence, Kosovo: The Financial Management of Military Operations, HC530 Session 1999-2000. London: The Stationary Office, at: http://www.nao.gov.uk/publications/nao_reports/9900530.pdf.

New York Times [NYT] (25/11/04a) 'FBI Interviews Halliburton Whistleblower', at: http://www.nytimes.com/aponline/national/AP-Halliburton.html.

NYT (25/11/04b) 'Pentagon Auditor Urges Army to Withhold Some Payments to Halliburton', at: http://www.nytimes.com/2004/11/25/politics/25halliburton.html.

NYT (3/2/05) 'US Army Won't Withhold Payment to Halliburton', at: http://www.nytimes.com/reuters/business/business-iraq-halliburton.html.

NYT (15/3/05) 'Excess Fuel Billing by Halliburton in Iraq Is Put at $\$ 108$ Million', at: http://www.nytimes.com/2005/03/15/politics/15halliburton.html.

Nossal, Kim Richard (2001) 'Global Governance and National Interests: Regulating Transnational Security Corporations in the Post-Cold War Era', Melbourne Journal of International Law 2(2): 459-476.

Observer (28/11/04) 'Revealed: How Britain Was Told Full Coup Plan', at: http://www.guardian.co.uk/equatorialguinea/story/0,15013,1361342,00.html.

Pint, Ellen M and Hart, Rachel (2001) Public-Private Partnerships: Proceedings of the U.S.-U.K. Conference on Military Installation Assets, Operations and Services (RAND, CF-164-A), at http://www.rand.org/publications/CF/CF164/CF164.pdf.

Silverstein, Ken (1997) 'Privatizing War. How Affairs of State Are Outsourced to Corporations Beyond Public Control', National Magazine, 4 August 1997, at: http//:faculty.lls.edu/ $\square$ manheim/ns/priv_war.htm

Singer, Peter W. (2003) Corporate Warriors. The Rise of the Privatized Military Industry. Ithaca, NY: Cornell University Press.

SIPRI (2005) 'Mergers, Acquisitions and Joint Ventures', at: http://www.sipri.org/contents/milap/milex/aprod/m_and_a_jv.htm.

Skoens, Elisabeth and Wulf, Herbert (1994) 'The Internationalization of the Arms Industry', Annals of the American Academy of Political and Social Science 535: 43-57. 
Smith, Ron (1993) 'Resources, Commitments and the Defence Industry', in Michael Clarke and Philip Sabin (eds.) British Defence Choices for the Twenty-First Century, pp.73-89. London: Brassey's.

Spearin, Christopher (2003) 'American Hegemony Incorporated: The Importance and Implications of Military Contractors in Iraq', Contemporary Security Policy 24(3): 26-47.

Sunday Times (3/5/98) 'Cook Snared in Arms for Coup Inquiry', at: http://www.timesarchive.co.uk/news/pages/sti/98/05/03/stinwenws 01026.html?1621558.

Taulbee, James Larry (2000) 'Mercenaries, Private Armies and Security Companies in Contemporary Policy', International Politics 37(4): 433-456.

Times (4/5/98) 'Cook Faces Commons Row over Arms Deal Licences', at: http://www.timesarchive.co.uk/news/pages/tim/98/05/04/timf gnafr02002.html?1621558.

United States Government [USG] (2004) 'Interagency Policy Memorandum - Contractor Security in Iraq', 30 June, at: http://ipoaonline-iraq.org/archives/Joint\%20DOS-DOD\%20letter.doc, last accessed 17 March 2005.

Zarate, Juan Carlos (1998) 'The Emergence of a New Dog of War: Private International Security Companies, International Law and the New World Disorder', Stanford Journal of International Law 34(1): 75-162.

\footnotetext{
${ }^{1}$ The following will use apostrophes for 'government' and 'governance' when speaking of these ideal types as examples of governing structures, whereas government without apostrophes will refer to national executives and their agencies.

${ }^{2}$ Measures of de-governmentalisation have been proposed elsewhere, see for instance Klaus Dieter Wolf (2001) 'Private Actors and the Legitimacy of Governance Beyond the State', paper presented at the ECPR workshop 'Governance and Democratic Legitimacy', Grenoble 6-11 April, at: http://www.essex.ac.uk/ecpr/jointsessions/grenoble/ papers/ws5/wolf/pdf. However, a detailed assessment of the degree of de-governmentalisation is beyond the scope of this article which first seeks to demonstrate the relevance of the governance concept for the analysis of transatlantic security.

${ }^{3}$ More recent statements argue that ' $[\mathrm{t}]$ here is no predisposition towards either public or private sector' and that the MoD is taking a 'pragmatic' approach. See 'Public Private Partnerships in the MoD', at: http://www.mod.uk/business/ppp/intro.htm, last accessed 6 June 2004.
} 